\title{
Research regarding the cover factor of magnetron sputtering plasma coated fabrics
}

Cercetari privind factorul de acoperire al țesăturilor pulverizare în plasma tip magnetron

Domeniul textilelor tehnice Buildtech necesită noi tehnologii pentru fabricarea materialelor flexibile ecologice. Pulverizarea prin magnetron permite acoperirea la scară nanometrică a țesăturilor cu diferite funcționalități și beneficii. Funcțiile noi ale țăsăturilor constau în ecranarea electromagnetică și ignifugare. Studiul urmărește să analizeze factorul de acoperire al țesăturilor prin pulverizare în plasmă și a țesăturilor crude, destinate funcționalităților menționate mai sus. Tesăturile cu compoziție fibroasă de 100\% bumbac și 100\% poliester au fost acoperite cu pelicule de Cu prin pulverizare tip magnetron, pentru a conferi conductivitate electrică de suprafață și caracter ignifug. Densitatea țesăturii și diametrul firelor au fost determinate pentru țesăturile acoperite în plasmă și pentru cele crude, cu scopul de a calcula factorul de acoperire, în timp ce testele de absorbție atomică au fost efectuate pentru a determina conținutul de cupru depus. Factorul de acoperire al țesăturii acoperite în plasmă scade ușor în funcție de timpul de procesare pentru cele patru probe analizate în cadrul studiului. Acest comportament fizic este subliniat de imaginile de microscopie optică ale țesăturilor crude și a celor acoperite și poate fi explicat prin scăderea ușoară a diametrului firului după acoperire în plasmă. Mai mult, țesăturile acoperite obținute au prezentat o bună performanță în ceea ce privește ecranarea electromagnetică, măsurată cu celulele TEM și un caracter ignifug, evidențiat prin determinarea punctului de topire.

Cuvinte-cheie: ignifugare, ecranare electromagnetică, elemente de construcție, bumbac, probe PES

\section{Research regarding the cover factor of magnetron sputtering plasma coated fabrics}

Buildtech technical textiles domain requires new technologies for manufacturing flexible eco-friendly materials. Magnetron sputtering allows nanometer scale coatings on fabrics with various functionalities and benefits. Novel fabric functionalities consist in electromagnetic shielding and fireproofing. This paper aims to analyse the cover factor of raw and plasma coated fabrics, meant for the above mentioned functionalities. Fabrics with fibrous composition of $100 \%$ cotton and $100 \%$ polyester (PES) were coated with Cu films by magnetron sputtering in order to render surface electrical conductivity and fireproof character. Fabric density and yarn diameter were determined for raw and plasma coated fabrics in order to compute the cover factor, while atomic absorption tests were performed in order to determine the content of deposited copper. The cover factor of plasma coated fabric slightly decreases as a function of the process time for the four analysed samples within the study. This physical behaviour is underlined by optical microscope images of raw and coated fabrics and can be explained through slight decrease of yarn diameter after plasma magnetron coating. Moreover, obtained coated fabrics presented good performance regarding electromagnetic shielding, measured with TEM cell and fire-proofing character, evidenced by melting point determination.

Keywords: fireproofing, electromagnetic shielding, building elements, cotton, PES samples

\section{INTRODUCTION}

Safety and protection of human's health against various external factors has been always a priority. Electromagnetic interference is nowadays increasing due to the accelerated development of telecommunication. The shielding of electromagnetic radiation is especially important for the preservation of human's health and proper functioning of electronic equipment. The specifications imposed for the materials used for electromagnetic shielding depend on the shielding application requirements. In the case of Buildtech technical textiles, metallic braids or metallic coated fabrics are considered in order to improve shielding effectiveness [1-2].
Fire may be an enemy for humans, if it takes one unprepared. In combination with highly flammable materials, flames may generate real disasters. Classical textile materials for home textiles, upholster etc., have a great disadvantage: they are highly flammable due the fibers they are made of, either consisting of natural fibers (linen, hemp, cotton, wool and blends thereof) or of synthetic fibers. In order to prevent undesired events and to avoid disasters, textile materials may be functionalized by specific substances and become thus not only a solution for design and comfort, but a solution for safety as well. Fireproofing of textile materials [3] represents nowadays the most advanced procedure of fighting against accidents caused by flames. 
Plasma coating may be used to impart various other functionalities to textile materials: anti-static, antimicrobial, fireproof, anti-felting (for wool), hydrophilic, hydro-/oleo phobic etc. [4]. Magnetron sputtering technique for rendering electrical conductivity to textile fabrics has been reported in the scientific literature. PP nonwoven fabrics were coated with $\mathrm{Zn}-\mathrm{Bi}$ metal particles for achieving electromagnetic shielding of about $40 \mathrm{~dB}$ [5-6]. In order to render electrical surface conductivity for textile fabrics, carbon nanotubes were attached on PET fabrics by means of oxygen plasma pre-treatment and subsequent acrylic acid grafting [7], while shielding properties were assessed by absorption loss measurement via vector network analyzer [8]. Electromagnetic shielding was achieved on fabrics as well with other modern techniques, such as coating with carbon or PEDOT-PSS conductive polymers [9], or printing technique [10]. Measurement of shielding effectiveness was usually performed via coaxial TEM cell, according to ASTM D-4935 standard for plane materials $[11,12]$. On the other hand, plasma coating for fireproofing textiles is a relative recent technique. Plasma induced graftpolymerization was applied in order to impart fireproof properties on cotton textiles [13], PAN fabrics [14] and silk [15]. Other research studies reported activation of wool fabrics via ultrasonic waves and treatment by organic di-carboxylic acids in order to increase uptake of zirconium and titanium salts, which improve their fireproofing [16]. Good results of fire proofing silk fabrics by means of flavonoids-metal salts combination was reported in [17]. An optimization study on fire proofing of cotton woven fabrics was performed by means of classical finishing agents, having as independent parameters solution concentration, temperature and process time [18]. Industrial upscale of plasma technologies for textiles is nevertheless still limited, for various reasons such as: different deposition on warp and weft, irregular deposition compared to padding and the large dimensions of fabrics [19].
The present research study tackles the optimal woven fabric structure with EM shielding and fireproof properties destined to the Buildtech domain. This paper focuses on the analysis of cover factor [20-21] for raw and plasma coated fabrics used within the research study.

\section{MATERIALS AND METHODS}

In order to obtain adequate flexible eco-friendly materials for BUILDTECH domain with fireproof and electromagnetic shielding character, various samples of woven fabrics were manufactured, coated with magnetron plasma and tested.

\section{Materials}

Woven fabrics from 100\% cotton (BBC) and 100\% polyester (PES) were used for this purpose. Several samples with various yarn count, density and specific mass were designed and manufactured. Raw materials and fabric structure were selected in order to meet requirements of Buildtech technical textiles: good mechanical resistance, light weight and costeffectiveness. For studying the cover factor, two samples from $100 \%$ cotton and two samples from $100 \%$ PES were selected and coated by magnetron plasma with copper films of 400 and $1200 \mathrm{~nm}$. Raw and coated fabric samples were comparatively assessed. Table 1 presents the physical-mechanical properties of yarns used for the four fabric samples.

Table 2 presents physical-mechanical properties of the four raw fabric samples.

\section{Methods}

The $\mathrm{Cu}$ coating of the textile fabrics was performed into a dedicated spherical stainless steel vacuum chamber (K.J. Lesker), pumped out by an assembly of a fore pump and turbomolecular pump (Pfeiffer), which allowed the obtaining of a base pressure prior deposition down to $3 \times 10^{-5}$ mbar. The chamber is provisioned with a Magnetron Sputtering Source from K.J. Lesker, accommodating 2" diameter Cu target of purity $99.999 \%$. The fire-resistant pre-treated cotton

Table 1

\begin{tabular}{|c|c|c|c|c|c|c|}
\hline \multicolumn{7}{|c|}{ PHYSICAL-MECHANICAL PROPERTIES OF YARNS INCLUDED IN THE RAW FABRICS } \\
\hline \multirow{2}{*}{ Property } & \multirow{2}{*}{\multicolumn{2}{|c|}{ Unit }} & Sample A. & Sample B. & Sample C. & Sample D. \\
\hline & & & $100 \%$ cotton & $100 \%$ PES & $100 \%$ cotton & $100 \%$ PES \\
\hline \multirow{4}{*}{ Yarn fineness } & \multirow{2}{*}{ tex $(\mathrm{Nm})$} & Warp & $53.51 \times 1(18.69 / 1)$ & - & $91.68 \times 1(10.9 / 1)$ & - \\
\hline & & Weft & $51.94 \times 1(19.25 / 1)$ & - & $93.15 \times 1(10.7 / 1)$ & - \\
\hline & \multirow{2}{*}{ dtex (den) } & Warp & - & $122 \times 1(109.8 \times 1)$ & - & $352.4 \times 1(317.2 \times 1)$ \\
\hline & & Weft & - & $121 \times 1(108.9 \times 1)$ & - & $339.1 \times 1(305.2 \times 1)$ \\
\hline \multirow{2}{*}{ Tensile strength } & \multicolumn{2}{|l|}{$\mathrm{N}$} & 4.97 & 11.40 & 6.50 & 13.69 \\
\hline & \multicolumn{2}{|l|}{ Cv\% } & 12.72 & 1.56 & 14,6 & 2.06 \\
\hline \multirow{2}{*}{$\begin{array}{l}\text { Relative } \\
\text { elongation }\end{array}$} & \multicolumn{2}{|l|}{$\%$} & 6.03 & 17.59 & 5.5 & 34.53 \\
\hline & \multicolumn{2}{|l|}{$\mathrm{Cv} \%$} & 11.01 & 3.89 & 12.3 & 7.37 \\
\hline \multirow{2}{*}{ Yarn diameter } & \multirow{2}{*}{$\mu \mathrm{m}$} & Warp & 296.4 & 152 & 458.2 & 326 \\
\hline & & Weft & 311.2 & 134 & 397 & 310 \\
\hline
\end{tabular}




\begin{tabular}{|c|c|c|c|c|c|}
\hline Property & Unit & Sample A. & Sample B. & Sample C. & Sample D. \\
\hline Fiber composition & Raw material & $100 \%$ cotton & $100 \%$ PES & $100 \%$ cotton & $100 \%$ PES \\
\hline Specific mass & $\mathrm{g} / \mathrm{m}^{2}$ & 231 & 88 & 416 & 207 \\
\hline Density Warp & No. yarns $/ 1 \mathrm{~cm}$ & 30 & 41 & 26.4 & 36.4 \\
\hline Density Weft & No. yarns $/ 1 \mathrm{~cm}$ & 16 & 28 & 16.6 & 21.4 \\
\hline Tensile strenght Warp & $\mathrm{N}$ & 910 & 937 & 1318 & 2345 \\
\hline Tensile strength Weft & $\mathrm{N}$ & 363 & 644 & 891 & 1331 \\
\hline Rel. Elong. Warp & $\%$ & 10.61 & 27.2 & 23.7 & 40.0 \\
\hline Rel. Elong. Weft & $\%$ & 8.63 & 28.5 & 12.85 & 38.2 \\
\hline
\end{tabular}

fabrics of $20 \mathrm{~cm}$ diameter were mounted inside the chamber, on a substrate holder placed at $14 \mathrm{~cm}$ inclined with respect to the magnetron. In order to enhance the deposition uniformity, the samples were rotating during the process with a constant speed of 200 rotation/min. An Ar flow (99.99\%) of $50 \mathrm{sccm}$ was continuously introduced in the chamber during the process by means of a Bronkhorst mass flow controller, so that the pressure established during the process was $5.3 \times 10^{-3} \mathrm{mbar}$. The discharge was ignited at $100 \mathrm{~W}$ by using an Advanced Energy RF generator $(13.56 \mathrm{MHz})$ - model CesarR provisioned with an automatic matching box for adapting the impedance; under the described experimental conditions, the measured deposition rate of $\mathrm{Cu}$ at the substrate level was around $9 \mathrm{~nm} / \mathrm{min}$. The deposition time was set such as to insure a coating thickness of $400 \mathrm{~nm}$ (45 $\mathrm{min}$ ) and $1200 \mathrm{~nm}$ (135 $\mathrm{min}$ ) onto the textile.

\section{The cover factor relation}

The cover factor indicates the degree in which the surface of a fabric is covered by a set of yarns. One method of calculating the cover factor of fabrics is function of yarn diameter and fabric density, according to relation (1) [20].

$$
e_{t}=d_{u} \cdot P u+d_{b} \cdot P b-d_{u} \cdot P u \cdot d_{b} \cdot P b
$$

Where following notations apply:

$e_{t}$ is Cover factor;

$d_{u}$ - diameter warp yarn $(\mu \mathrm{m})$;

$P u$ - fabric density warp (number of yarns $/ 10 \mathrm{~cm}$ );

$d_{b}$ - diameter weft yarn $(\mu \mathrm{m})$;

$\mathrm{Pb}-$ fabric density weft (number of yarns $/ 10 \mathrm{~cm}$ ).

\section{RESULTS}

In order to be able to compute the cover factor, yarn diameter and fabric density were measured for the raw and plasma coated fabric samples. Yarn diameter was measured via the optical microscope Projectina, by assessing width of yarn to microscope scale in micrometer, while fabric density was determined according to standard EN 1049-2/2000 method $A$ and $B$.

Moreover, optical microscope images were taken for raw and plasma coated fabrics, in order to assess the structure of yarns surface and to verify the influence of plasma coating on the diameter of yarns. Table 3 presents values for density and diameter of raw and plasma coated fabrics, destined for computing the cover factor, according to relation (1).

Figure 1 shows optical microscope images of the fabric surface of $100 \%$ cotton sample $A$, in raw (figure $1, a$ ) and plasma coated condition (figure $1, b$ ), with a magnification of $\times 5$.

Table 3

\begin{tabular}{|c|c|c|c|c|c|c|}
\hline \multirow[t]{2}{*}{ Sample } & \multirow[t]{2}{*}{ Treatment } & \multicolumn{4}{|c|}{ Experimental data } & \multirow{2}{*}{$\begin{array}{c}\text { Result } \\
\text { Cover factor }\end{array}$} \\
\hline & & Density Warp & Density Weft & Diameter Warp & Diameter Weft & \\
\hline & & \multicolumn{2}{|c|}{ No. yarns $/ 1 \mathrm{~cm}$} & \multicolumn{2}{|c|}{$\mu m$} & \\
\hline \multirow{3}{*}{ Sample A. } & RAW & 30 & 16 & 308.4 & 331.2 & 0.96483802 \\
\hline & P1-Plasma $45 \mathrm{~min}$ & 30.2 & 16.4 & 310 & 318 & 0.96947298 \\
\hline & P2-Plasma $135 \mathrm{~min}$ & 30 & 16.2 & 306 & 310 & 0.9591804 \\
\hline \multirow{3}{*}{ Sample B. } & RAW & 41 & 28 & 152 & 134 & 0.76457536 \\
\hline & P3-Plasma $45 \mathrm{~min}$ & 41 & 28.4 & 120 & 126 & 0.67378272 \\
\hline & P4-Plasma $135 \mathrm{~min}$ & 40.4 & 28.4 & 118 & 120 & 0.65505382 \\
\hline \multirow{3}{*}{ Sample C. } & RAW & 26.4 & 16.6 & 458.2 & 397 & 1.07148578 \\
\hline & P5-Plasma $45 \mathrm{~min}$ & 26 & 16 & 376 & 424 & 0.99279616 \\
\hline & P6-Plasma $135 \mathrm{~min}$ & 26.4 & 16.4 & 388 & 396 & 1.00852562 \\
\hline \multirow{3}{*}{ Sample D. } & RAW & 36.4 & 21.4 & 326 & 310 & 1.06282302 \\
\hline & P7-Plasma $45 \mathrm{~min}$ & 37 & 22 & 258 & 276 & 0.98216688 \\
\hline & P8-Plasma $135 \mathrm{~min}$ & 37 & 22 & 222 & 244 & 0.91727248 \\
\hline
\end{tabular}




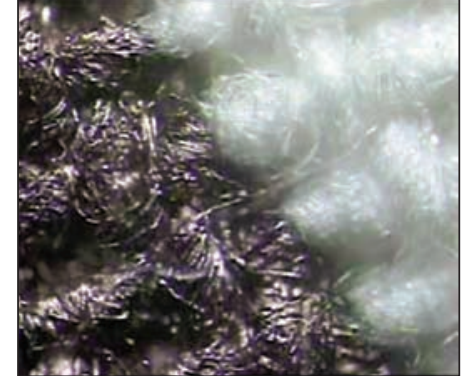

a

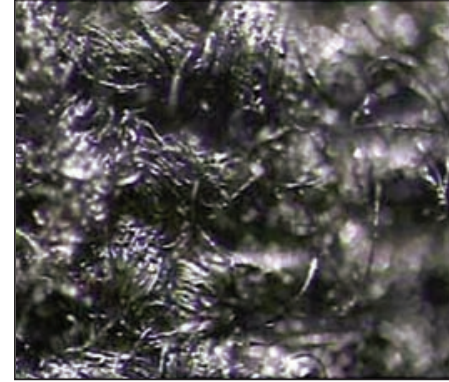

b
Fig. 1. a - Surface structure of raw/plasma coated cotton fabric; $b$ - surface structure of plasma coated cotton fabric

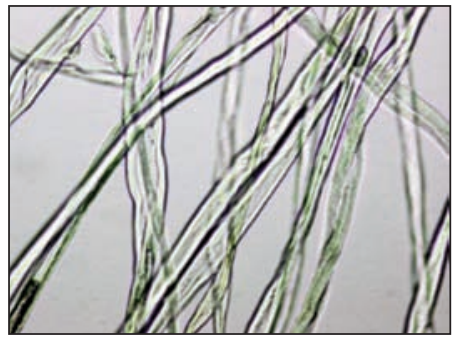

a

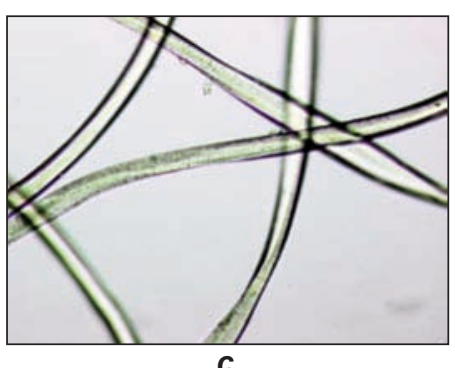

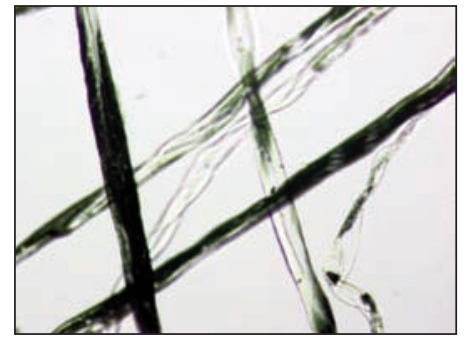

b

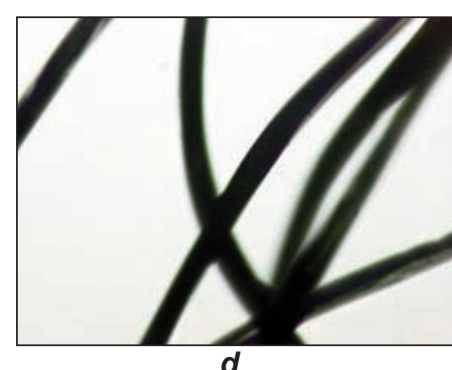

d
Fig. 2. Optical microscopy images (magnification $\times 40$ ) of fibers from raw and plasma coated cotton $(a, b)$ and respectively PES $(c, d)$ fabrics

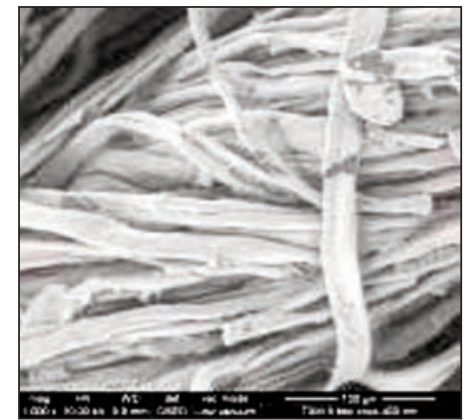

a

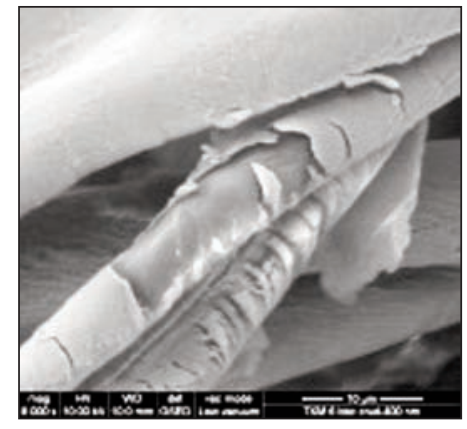

c
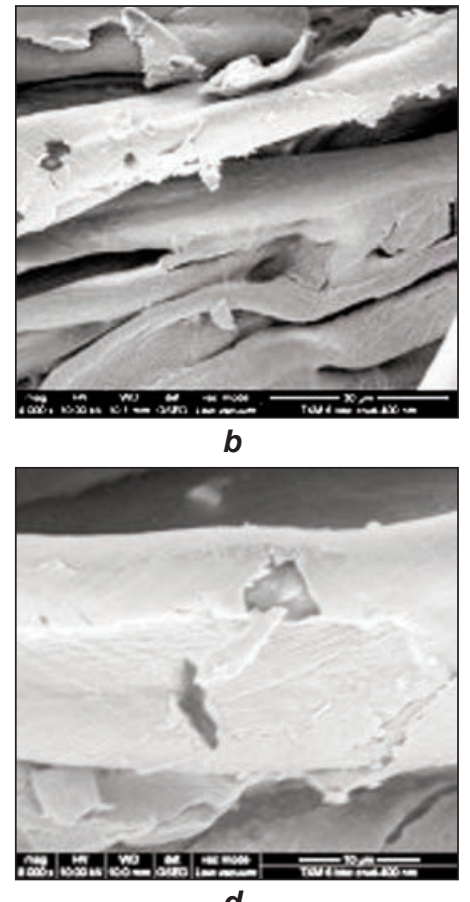

d
Fig. 3. SEM images of plasma coated cotton fabrics (Cu film of $400 \mathrm{~nm}$ ), taken at various magnifications: $a-\times 1000 ; b-\times 2000$; $c-\times 4000 ; d-\times 8000$
Figure 1 evidences shrinkage of yarn diameter after plasma coating, due to deposition of copper film onto bulk textile material. Figure 2 presents optical microscopy images of fibers taken out of $100 \%$ cotton and $100 \%$ PES fabric samples in raw and plasma coated condition, in which the blackish regions of the fibers evidence the $\mathrm{Cu}$ coated regions. Figure 2 presents optical microscope images of fibers extracted from raw and coated cotton and PES fabrics, with a magnification of $\times 40$.

Figure 3 presents SEM images of cotton fibers deposited with $400 \mathrm{~nm}$ copper thin films. They evidence on one hand the uniform aspect of the coating onto the fibers, but also the presence of few cracks and small portion of delamination.

Atomic absorption tests were performed on AAS 880 Varian spectrometer in order to determine the content of deposited copper in mg per $\mathrm{g}$ of coated textile fabrics. Four different measurements were performed for each type of sample, and table 4 includes the averaged results of the four types of fabric samples coated for $45 \mathrm{~min}$ and $135 \mathrm{~min}$.

Results of atomic absorption evidence deposited copper content on textile fabrics. Substantial copper concentrations of 51-172 $\mathrm{mg} \mathrm{Cu} / \mathrm{g}$ of material could be determined. All fabrics coated for 135 min showed larger copper content than fabrics coated for 45 $\min$. Moreover, both fabrics of $100 \%$ cotton and $100 \%$ PES with lower specific mass (sample A and B) presented a higher amount of $\mathrm{Cu}$ into the structure, due to the fact that same $\mathrm{Cu}$ thickness was deposited onto all samples, regardless their specific mass. Highest amount of $\mathrm{Cu}$ was obtained for Sample B coated for $135 \mathrm{~min}(1200 \mathrm{~nm}$ thin film), which led to $172 \mathrm{mg} \mathrm{Cu/g}$ material.

Functional properties for electromagnetic shielding were achieved for plasma coated samples on both sides of the fabric, with results presented for sample D in figure 4 . Special functional properties for fireproofing character were achieved for $100 \%$ PES samples coated with silicon oxide. Melting point has increased from $254,4^{\circ} \mathrm{C}$ of raw materials to $258,2^{\circ} \mathrm{C}$ for fabric samples treated with silicon oxide (according to SR 13231:1994).

\section{DISCUSSION}

The values of cover factor as in table 3 show that this fabric parameter is decreasing with plasma coating. Smaller values are obtained for a longer process time (135 min when compared to $45 \mathrm{~min}$ ). This is mainly due to shrinkage of yarn diameter, while fabric density only slightly decreases, with values within the margin of error. Optical microscope images show that yarns coated with $\mathrm{Cu}$ thin 


\begin{tabular}{|c|c|c|c|c|c|c|c|c|}
\hline \multirow{2}{*}{ Sample } & \multicolumn{2}{|c|}{$\begin{array}{c}\text { Sample A } \\
(100 \% \text { cotton })\end{array}$} & \multicolumn{2}{|c|}{$\begin{array}{c}\text { Sample B } \\
(100 \% \text { PES) }\end{array}$} & \multicolumn{2}{|c|}{$\begin{array}{l}\text { Sample C } \\
(100 \% \text { cotton })\end{array}$} & \multicolumn{2}{|c|}{$\begin{array}{c}\text { Sample D } \\
\text { (100\% PES) }\end{array}$} \\
\hline & $\begin{array}{c}\text { P1 - } \\
\text { Plasma } \\
45 \text { min }\end{array}$ & $\begin{array}{c}\text { P2 - } \\
\text { Plasma } \\
135 \text { min }\end{array}$ & $\begin{array}{c}\text { P3 - } \\
\text { Plasma } \\
45 \text { min }\end{array}$ & $\begin{array}{c}\text { P4 - } \\
\text { Plasma } \\
135 \text { min }\end{array}$ & $\begin{array}{c}\text { P5 - } \\
\text { Plasma } \\
45 \text { min }\end{array}$ & $\begin{array}{c}\text { P6 - } \\
\text { Plasma } \\
135 \text { min }\end{array}$ & $\begin{array}{c}\text { P7 - } \\
\text { Plasma } \\
45 \text { min }\end{array}$ & $\begin{array}{c}\text { P8 - } \\
\text { Plasma } \\
135 \text { min }\end{array}$ \\
\hline $\begin{array}{l}\text { Cu quantity } \\
\text { reported on } \\
1 \mathrm{~g} \text { material } \\
(\mathrm{mg} / \mathrm{kg})\end{array}$ & 257.5 & 290.12 & 6.94 & 15.69 & 45.28 & 43.74 & 22.76 & 51.01 \\
\hline
\end{tabular}

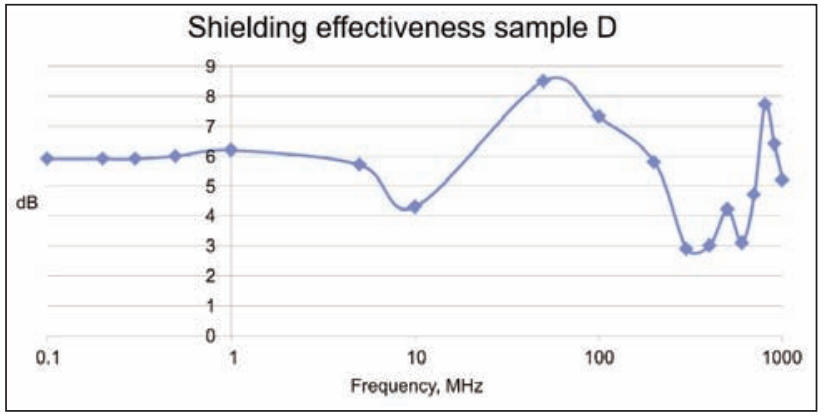

Fig. 4. Shielding effectiveness $100 \%$ PES fabric sample $\mathrm{D}$ coated on both sides

films by magnetron sputtering plasma have a shrinkage tendency, with effect on yarns diameter. This is mainly to bulk properties of raw cotton fabrics and its contraction under bombardment with $\mathrm{Cu}$ atoms provided by the sputtering process, which lead to $\mathrm{Cu}$ thin film deposition. PES fabrics undergo a similar physical modification, after sputtering plasma coating. Uniform copper film deposition of fabrics was evidenced by SEM images. The $\mathrm{Cu}$ concentration in $\mathrm{mg} / \mathrm{g}$ of material was determined by atomic absorption, showing an increase of content with the deposition time both for cotton and PES fabrics. Proposed functionalities for building elements, such as electromagnetic shielding and fireproofing character were evidenced by TEM cell measurements and melting point temperature, with good results: $6-8 \mathrm{~dB}$ shielding effectiveness for double side coated sample $D$ in the frequency range of $0,1-1000 \mathrm{MHz}$ and an increase of melting point of $4{ }^{\circ} \mathrm{C}$ for silicon oxide coated PES fabrics. Both these functionalities are going to be further improved within the research study.

\section{CONCLUSION}

The research study envisaged flexible materials for BUILDTECH domain, having fireproof and electro- magnetic shielding functionalities. These functionalities were achieved by an innovative manufacturing technology, namely magnetron plasma coating on textile fabrics. This paper focuses on a single aspect of the obtained fabrics: their cover factor. Cover factor of a woven fabric is expressed in relation to yarn diameter and fabric density. These two parameters were investigated for $100 \%$ cotton and $100 \%$ PES raw and plasma coated fabrics. The four analyzed fabrics presented lower cover factor when coated with plasma sputtering than the raw samples. This is mainly due to shrinkage of yarn diameter upon exposure to energetic $\mathrm{Cu}$ atoms originating from the magnetron sputtering plasma, while the fabric density remains unaffected.

For the future, the research study envisages integration within building walls of shielding materials to reduce the electromagnetic interference upon inside electronic equipment and to simultaneous have fireproof character. Such materials have to be cost-effective and eco-friendly, a further aim of our research study. The research study for achieving woven fabrics with electromagnetic shielding and fireproof properties have been performed within the project with title "Manufacturing textiles with electromagnetic shielding and fire-retardant properties by plasmabased methods" (Acronym TexEMFiRe).

\section{ACKNOWLEDGEMENTS}

Research work for this study has been performed within ERA-NET Manunet project C28/2018 TexEMFiRe and Nucleus project PN19150101, while publishing has been funded by Ministry of Research and Innovation, by Program 1 - Development of the national system for research-development, Subprogram 1.2 - Institutional performance - projects for funding excellence in RDI, contract no. 6PFE from 16.10.2018.

\section{BIBLIOGRAPHY}

[1] Schwab, A., Kuerner, W. Electromagnetic compatibility, Chapter 6 - Electromagnetic shielding, Editura AGIR, 2013.

[2] Paul, C.R. Electromagnetic compatibility, Chapter 8 - Shielding, Wiley Inter-science, 2006.

[3] Shishoo, R. (editor) Plasma technologies for textiles, Chapter 11: Marcandalli B. - Plasma treatments of fibres and textiles, Woodhead Publishing 2007.

[4] Sparavigna, A. Plasma treatment advantages for textiles, Dipartimento di Fisica, Politecnico di Torino, Torino, Italy (2008), Internet resource URL: https://arxiv.org/ftp/arxiv/papers/0801/0801.3727.pdf 
[5] Ziaja, J., Koprowska, J., Janukiewicz, J. Using plasma metallization for manufacture of textile screens against electromagnetic fields, In: FIBRES \& TEXTILES in Eastern Europe January / December / A 2008, Vol. 16, No. 5 (70) pp. 64-66.

[6] Ziaja, J., Jaroszewski, M. EMI shielding using composite materials with plasma layers, InTechOpen, March 2011, https://www.intechopen.com/books/electromagnetic-waves/emi-shielding-using-composite-materials-with-plasmalayers

[7] Haji, A., Rahbar, R. S., Shoushtari, A. M. Plasma assisted attachment of functionalized carbon nanotubes on PET fabric to improve electrical conductivity, In: POLIMERY 2015, 60, no. 5.

[8] Haji, A., Rahbar, R. S., Shoushtari A. M. Improved microwave shielding behavior of carbon nanotube-coated PET fabric using plasma technology, In: Applied Surface Science 311, 2014, pp. 593-601.

[9] Rubezien, V., Abraitiene, A. et al. Development and investigation of electromagnetic shielding fabrics with different conductive additives, In: Journal of Electrostatics, 75, 2015, pp. 90-98.

[10] Wang, L., See, K.Y., Richard, W. Y. Electromagnetic shielding analysis of printed flexible meshed screens. In: May 2010, ResearchGate.

[11] Badic, M., Marinescu, M. On the complete theory of coaxial TEM cells, In: IEEE Int. Symposium on Electromagnetic Compatibility, vol. 2, pp. 897-902, 2000.

[12] David, V., Vremera, E., Salceanu, A., Nica, I. On the characterization of electromagnetic shielding effectiveness of materials, In: January 2007, ResearchGate.

[13] Tsafack, M.J., Levalois-Grützmacher, J. Towards multifunctional surfaces using the plasma-induced graftpolymerization (PIGP) process: Flame and waterproof cotton textiles, In: Surface \& Coating Technology, 201 (2007), pp. 5789-5795.

[14] Tsafack, M.J., Levalois-Grützmacher, J. Plasma-induced graft-polymerization of flame retardant monomers onto PAN fabrics, In: Surface \& Coatings Technology 200, 2006, pp. 3503-3510.

[15] Paosawatyanyonga, B., Bhanthumnavind, W. Graft copolymerization coating of methacryloyloxyethyl diphenylphosphate flame retardant onto silk surface, In: Progress in Organic Coatings 77, 2014, pp. 1585-1590.

[16] Salama, M., Bendak, A., Moeller, M. Activating wool for flame-proof treatments with zirconium and titanium salts, In: Industria textila, 2011, vol. 62, nr. 6.

[17] Zhou, Y., Tang, R.C. et. al. Flavonoids-metal salts combination: A facile and efficient route for enhancing the flame retardancy of silk, In: Industrial Crops \& Products 130, 2019, pp. 580-591.

[18] Gherasimescu, C., Muresan, A., Leva, M., Manea, L.R., Butnaru, R. Research regarding the optimization of flame retardant treatment for cellulose textile materials, In: Industria textila, 2011, vol. 62, nr. 1.

[19] Buyle G. Nanoscale finishing of textiles via plasma treatment, In: Materials Technology, vol. 24, nr. 1, pp. 46-51, 2009.

[20] Dodu, A. (coordinator), Manualul Inginerului Textilist, Sectiunea a 4-a: Țesătorie, In: IV.9 Bazele proiectării țesăturilor, pp. 1440-1450, Editura AGIR, 2005.

[21] Singh, R. Theory and calculation of cover factor of woven fabric, B.Tech, Dept. of Textile Engineering, Punjab Technical University Campus, Internet resource URL: http://textilelearner.blogspot.com/2013/07/theory-andcalculation-of-cover-factor.html

[22] Rădulescu, I.R., Visileanu, E., Pătru, I., Surdu, L., Costea, M., Voicu, V. Modelling and testing the electromagnetic near field shielding effectiveness achieved by woven fabrics with conductive yarns, In: Industria Textila vol. 69 , no. 3, 2018, pp. 169-176.

[23] Surdu, L., Rădulescu, I.-R., Barbu, I. Life cycle assessment for medical textiles treated with plasma, In: Industria Textila, vol. 66, no. 6, 2015, pp. 360-364.

[24] Surdu, L., Surdu, I., Rădulescu, I.-R. Research for accomplishing multifunctional textiles with plasma technology, In: Industria Textila, vol. 67, no. 5, 2016 pp. 314-321.

\section{Authors:}

LILIOARA SURDU ${ }^{1}$, EMILIA VISILEANU ${ }^{1}$, ION-RĂZVAN RĂDULESCU ${ }^{1}$, IRINA SANDULACHE ${ }^{1}$, CORNELIA MITRAN ${ }^{1}$, BOGDANA MITU², CRISTIAN STANCU², ALINA ARDELEANU²

${ }^{1}$ INCDTP - Bucharest, Str. L. Patrascanu 16, 030508, Bucharest, Romania

e-mail: certex@certex.ro

2INFLPR - Măgurele, Str. Atomistilor No. 409, 077125, Bucharest, Romania

e-mail: mitub@infim.ro

Corresponding author:

LILIOARA SURDU

e-mail: lilioara.surdu@certex.ro 